\title{
$\mathrm{Al}-5.2 \mathrm{Si}-3.4 \mathrm{Cu}-0.28 \mathrm{Mg}$ 합금의 미세조직 및 기계적 특성에 미치는 용체화 및 시효 열처리의 영향
}

\author{
조의제·정제기·박용호* \\ 부산대학교 재료공학과
}

\section{Effects of Solution and Aging Treatments on the Microstructure and Mechanical Properties of Al-5.2Si-3.4Cu-0.28Mg Alloy}

\author{
Yi Je Cho, Jeki Jung, and Yong Ho Park* \\ Department of Materials Science and Engineering, Pusan National University, Busan 46241, Republic of Korea
}

\begin{abstract}
Since strength and ductility have a trade-off relationship in $\mathrm{Al}$ alloys, controlling these properties using heat treatments requires careful attention to the dissolution and evolution of the reinforcing phases. In this study, the effects of solution and aging treatments on the microstructure and mechanical properties of $\mathrm{Al}-5.2 \mathrm{Si}-3.4 \mathrm{Cu}-0.28 \mathrm{Mg}$ alloy were investigated. 1-step and 2-step solution treatments were conducted at 495 and $520{ }^{\circ} \mathrm{C}$ with various holding times, which were determined by thermal analysis. At $495{ }^{\circ} \mathrm{C}$, the eutectic $\theta\left(\mathrm{Al}_{2} \mathrm{Cu}\right)$ phases were quickly dissolved while block-shaped $\theta$ phases remained, even until 13 hours. During the 2-step treatment at $520{ }^{\circ} \mathrm{C}$, these remaining phases were melted both in the grains and boundaries. Although all of the $\mathrm{Q}\left(\mathrm{Al}_{5} \mathrm{Cu}_{2} \mathrm{Mg}_{8} \mathrm{Si}_{6}\right)$ phases were completely dissolved in the 2 -step treatment, the hardness of the 2-step treated specimen was lower than the 1-step treated one. After solution treatments at $495{ }^{\circ} \mathrm{C} / 9$ hours, where the highest hardness was observed, artificial aging treatments were conducted at 160 and $200{ }^{\circ} \mathrm{C}$ with various times. Yield and ultimate tensile strengths showed similar values at the peak aging regardless of the temperature, while higher hardness (117\%) and elongation (281\%) were obtained at 160 than $200{ }^{\circ} \mathrm{C}$. Based on the observed results, the correlations between the microstructures and mechanical properties by the heat treatments were investigated.
\end{abstract}

(Received July 5, 2017; Accepted September 18, 2017)

Keywords: $\mathrm{Al}$ alloy, solution treatment, aging, microstructure, mechanical properties

\section{1. 서 론}

낮은 밀도, 고강도 및 우수한 내부식성, 주조성을 가지는 $\mathrm{Al}-\mathrm{Si}$ 합금은 자동차 산업에 광범위하게 적용되고 있다 [1]. $\mathrm{Al}-\mathrm{Si}$ 합금의 기계적 특성을 향상시키기 위해 $\mathrm{Mg}$ 와 $\mathrm{Cu}$ 를 첨 가하는데 이에 따른 장단점이 존재한다. $\mathrm{Mg}$ 의 첨가는 고용 및 석출 강화 기구로 기계적 특성을 향상시키지만, 주조 결함 의 발생 가능성이 증가하고 고온에서 $\mathrm{Mg}$ 를 함유한 석출상의 조대화가 일어난다 [2-4]. $\mathrm{Cu}$ 의 경우, 미세한 $\theta^{\prime}\left(\mathrm{Al}_{2} \mathrm{Cu}\right)$ 상에 의한 석출 강화와 취성의 $\mathrm{Fe}$ 화합물의 개량 처리 (modification)가 가능하지만, 내식성이 감소하고 열간 균열 에 대한 민감성이 증가한다 [5-9]. 이러한 이유로 요구되는

*Corresponding Author: Yong Ho Park

[Tel: +82-51-510-3967, E-mail: yhpark@pusan.ac.kr]

Copyright (c) The Korean Institute of Metals and Materials
기계적 특성을 만족시키기 위해, $\mathrm{Cu}$ 와 $\mathrm{Mg}$ 를 적절한 조합으 로 첨가한 $\mathrm{Al}-\mathrm{Si}-\mathrm{Cu}-\mathrm{Mg}$ 합금의 설계, 열처리 조건 변화 등 다 양한 연구가 활발히 진행되어 왔다 [6,10-14].

$\mathrm{Al}-\mathrm{Si}-\mathrm{Cu}-\mathrm{Mg}$ 합금의 열처리는 $490-505{ }^{\circ} \mathrm{C}$ 에서 용체화 후 $150-240{ }^{\circ} \mathrm{C}$ 에서 시효 열처리를 하는 경로를 따른다 [14-19]. 이러한 열처리는 $\theta\left(\mathrm{Al}_{2} \mathrm{Cu}\right)$ 상을 고용시키고, 미세한 $\theta^{\prime}\left(\mathrm{Al}_{2} \mathrm{Cu}\right)$ 상을 석출시키면서 기지와 부분 정합을 유지하도록 유도하는 것이 특징이다. 한편, 추가적인 고용 및 석출 경화 를 일으키기 위해, $505{ }^{\circ} \mathrm{C}$ 이하에서 용체화 이후 $520{ }^{\circ} \mathrm{C}$ 이상 에서 다시 용체화하여 $\mathrm{Q}\left(\mathrm{Al}_{5} \mathrm{Mg}_{8} \mathrm{Cu}_{2} \mathrm{Si}_{6}\right)$ 상을 고용시키고, 시 효 시 $\theta^{\prime}\left(\mathrm{Al}_{2} \mathrm{Cu}\right), \mathrm{Q}^{\prime \prime}\left(\mathrm{Al}_{5} \mathrm{Mg}_{8} \mathrm{Cu}_{2} \mathrm{Si}_{6}\right)$ 상을 석출시키려는 연구 도 시도되었다 $[13,20,21]$.

$\mathrm{Al}-\mathrm{Si}-\mathrm{Cu}-\mathrm{Mg}$ 합금에서 $\mathrm{Cu}, \mathrm{Mg}$ 의 첨가량 $(\mathrm{Cu}+\mathrm{Mg})$ 과 $\mathrm{Cu} / \mathrm{Mg}$ 의 비에 따라 생성되는 상이 달라질 뿐만 아니라, T6 
Table 1. Chemical composition of the alloy $(\mathrm{Cu}+\mathrm{Mg}=3.68 \mathrm{wt} \%$ and $\mathrm{Cu} / \mathrm{Mg}=12.1$ ).

\begin{tabular}{ccccccc}
\hline \multicolumn{7}{c}{ Chemical composition (wt\%) } \\
\hline Element & $\mathrm{Al}$ & $\mathrm{Si}$ & $\mathrm{Cu}$ & $\mathrm{Mg}$ & $\mathrm{Fe}$ & $\mathrm{Ti}$ \\
\hline & Bal. & 5.20 & 3.40 & 0.28 & 0.08 & 0.01 \\
\hline
\end{tabular}

열처리 시 강도 및 연성을 향상시키는 기구도 변화한다고 알 려져 있다 [13]. 기존에 보고된 $\mathrm{Al}-\mathrm{Si}-\mathrm{Cu}-\mathrm{Mg}$ 합금들은 $6 \mathrm{wt} \%$ 이상의 $\mathrm{Si}, 5 \mathrm{wt} \%$ 이하의 $\mathrm{Cu}+\mathrm{Mg}$ 및 $0.8-86.5$ 범위의 $\mathrm{Cu} / \mathrm{Mg}$ 비의 조성을 가졌다 [11-16,20,22,23]. 높은 $\mathrm{Cu}, \mathrm{Mg}$ 함량(3.5 wt\% 이상) 및 $\mathrm{Cu} / \mathrm{Mg}$ 비(6.5 이상) 조성의 $\mathrm{Al}-\mathrm{Si}-$ $\mathrm{Cu}-\mathrm{Mg}$ 합금은 $\mathrm{T} 6$ 열처리 후 $400 \mathrm{MPa}$ 이상의 높은 인장강도 를 가지지만, $1 \%$ 이하의 낮은 연신율을 나타냈다 $[10,12,16,20]$. 낮은 연신율의 원인은 높은 $\mathrm{Si}$ 첨가량(1)과 높 은 $\mathrm{Cu}, \mathrm{Mg}$ 첨가량에 따른 $\beta\left(\mathrm{Mg}_{2} \mathrm{Si}\right)$ 상 대신 $\theta$ 상의 생성 $(2)$, 높 은 $\mathrm{Cu} / \mathrm{Mg}$ 비에 따른 조대한 $\mathrm{Q}^{\prime}\left(\mathrm{Al}_{5} \mathrm{Mg}_{8} \mathrm{Cu}_{2} \mathrm{Si}_{6}\right)$ 상의 석출(3)이 다 [13,24,25]. 반면에, 낮은 $\mathrm{Cu}, \mathrm{Mg}$ 함량 $(1.1-2.3 \mathrm{wt} \%$ ) 및 $\mathrm{Cu} / \mathrm{Mg}$ 비(0.83-4) 조성의 합금에서는 연성이 확보되지만 강 도가 저하되는 문제점이 존재했다 [13,22,23].

매우 낮은 연성은 제품의 생산을 위한 재료의 후 가공 작업 에 악영향을 미치기 때문에 연성을 필수적으로 확보해야 한 다. 본 연구에서는 연성을 증가시키고 적절한 강도를 확보하 기 위해, $\mathrm{Si}$ 첨가량을 낮추고, $3.68 \mathrm{wt} \%$ 의 $\mathrm{Cu}+\mathrm{Mg}, 12.1$ 의 $\mathrm{Cu} / \mathrm{Mg}$ 비를 가지는 $\mathrm{Al}-5.2 \mathrm{Si}-3.4 \mathrm{Cu}-0.28 \mathrm{Mg}$ 합금에 대해, 열 처리 공정에 따른 미세조직 및 기계적 특성의 변화를 조사하 고 최적의 열처리 공정을 제시하고자 하였다. 용체화 열처리 온도, 시간에 따른 미세조직 및 경도 분석을 통해 열처리 조 건을 정하고, 시효 열처리 조건에 따른 기계적 특성을 평가하 여 열처리 조건을 도출하였다.

\section{2. 실험 방법}

순금속의 $\mathrm{Al}, \mathrm{Si}, \mathrm{Cu}, \mathrm{Mg}$ 을 흑연 도가니를 사용한 전기로 를 이용하여 $750{ }^{\circ} \mathrm{C}$ 에서 용해하였다. 용탕의 산화를 최소화 하기 위해 환원성 플럭스(flux)를 용탕 표면에 도포하고, 780 ${ }^{\circ} \mathrm{C}$ 까지 승온한 후 용탕의 가스 함유량을 낮추기 위해 $\mathrm{Ar}$ 가 스를 이용하여 GBF(gas bubbling filtration) 처리하였다. 200 ${ }^{\circ} \mathrm{C}$ 로 예열한 금형의 표면을 이형제로 도포하고, 용탕을 주입 하여 주조하였다. 제조된 as-cast 상태의 Al-5.2Si-3.4Cu$0.28 \mathrm{Mg}$ 합금의 조성을 표 1 에 나타내었다. 합금의 열적 거동 을 분석하기 위해, 승온 속도 $10{ }^{\circ} \mathrm{C} / \mathrm{min}$ 로 $\mathrm{Ar}$ 분위기에서 480 - $620{ }^{\circ} \mathrm{C}$ 범위에 대해 시차 열 분석기(differential thermal
Table 2. Conditions of solution and aging treatments.

\begin{tabular}{|c|c|c|}
\hline Heat-treatment & Temperature $\left({ }^{\circ} \mathrm{C}\right)$ & Time (min) \\
\hline \multirow{5}{*}{ Solution treatment } & \multirow{5}{*}{495} & 300 \\
\hline & & 420 \\
\hline & & 540 \\
\hline & & 660 \\
\hline & & 780 \\
\hline \multirow{3}{*}{$\begin{array}{c}\text { 2-step } \\
\text { solution treatment }\end{array}$} & \multirow{3}{*}{520} & 60 \\
\hline & & 180 \\
\hline & & 300 \\
\hline \multirow{11}{*}{ Aging treatment } & \multirow{6}{*}{160} & 60 \\
\hline & & 120 \\
\hline & & 240 \\
\hline & & 480 \\
\hline & & 720 \\
\hline & & 1200 \\
\hline & \multirow{5}{*}{200} & 10 \\
\hline & & 30 \\
\hline & & 50 \\
\hline & & 60 \\
\hline & & 120 \\
\hline
\end{tabular}

analysis, DTA; TG/DTA 7300, SEIKO, Japan)를 이용하여 시 험을 실시하였다.

표 2는 열 분석 결과를 바탕으로 선정된 열처리 조건을 나 타낸다. 열처리는 대기분위기에서 승온 속도 $10{ }^{\circ} \mathrm{C} / \mathrm{min}$ 로 실 시하였다. 용체화 열처리는 $495{ }^{\circ} \mathrm{C}$ 에서 5-13시간 실시하고 수냉하였고, 2 단 용체화 열처리의 경우 $495{ }^{\circ} \mathrm{C}$ 에서 1 단 용체 화 후 즉시 승온시켜 $520{ }^{\circ} \mathrm{C}$ 에서 $1-5$ 시간 유지하고 수냉하 였다. 시효 열처리는 $160-200{ }^{\circ} \mathrm{C}$ 온도 구간에서 10 분 -20 시간 시행 후 공냉하였다.

열처리 조건에 따른 미세조직 변화를 분석하기 위해 X선 회절기(X-ray diffractometer, XRD; MiniFlex, Rigaku, Japan), 광학 현미경(optical microscope, OM; GX41, Olympus, Japan), 주사 전자 현미경(field emission scanning electron micrscope, FE-SEM/EDS; MIRA III LMH; Tescan, Czech Republic)을 이용하였다. X선 회절 분석은 $30 \mathrm{kV}, 15$ $\mathrm{mA}$ 조건의 $\mathrm{Cu}-\mathrm{K} \alpha$ 선을 사용하였으며 $10-90^{\circ}$ 의 2theta 범 위에서 실시하였다. 미세조직 관찰을 위해 시편을 기계 연마 후 Keller reagent $\left(\mathrm{H}_{2} \mathrm{O} 190 \mathrm{~mL}, \mathrm{HNO}_{3} 5 \mathrm{~mL}, \mathrm{HCl} 3 \mathrm{~mL}\right.$, HF 2 $\mathrm{mL}$ )으로 에칭하였다. 경도 시험은 비커스 경도기(HM-124, Mitutoyo, Japan)를 이용하여 $9.8 \mathrm{~N}$ 의 주 하중으로 20 회씩 실 시하고 평균 값을 사용하였다. 인장 시험은 미국재료시험학 회(American society for testing and material, ASTM) E8 규 격으로 가공한 시편을 사용했고, 만능 재료 시험기(Keithley $\mathrm{US} / 2400, \mathrm{R} \& \mathrm{~B}$ Korea, Korea)를 이용하여 변형 속도 $1.3 \times$ 

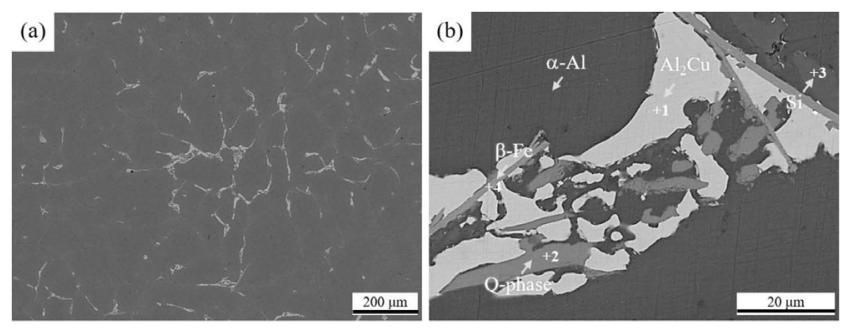

Fig. 1. (a) BSE image of as-cast alloy, and (b) enlarged image with EDS results.

$10^{-4} \mathrm{~s}^{-1}$ 로 실시하였다.

\section{3. 결과 및 고찰}

그림 1과 표 3은 SEM으로 관찰한 $\mathrm{Al}-5.2 \mathrm{Si}-3.4 \mathrm{Cu}-0.28 \mathrm{Mg}$ 합금의 as-cast 미세조직의 후방산란전자(back scattered electron, BSE) 이미지와 각 상들의 EDS 분석 결과를 나타낸 다. 회백색 상들이 망상으로 분포되어 있고(그림 1(a)), 이 망 상 조직은 $\mathrm{Al}-\mathrm{Si}$ 공정상 주위로 블록 형태 또는 공정의 $\theta$ $\left(\mathrm{Al}_{2} \mathrm{Cu}\right)$ 상 및 $\mathrm{Q}\left(\mathrm{Al}_{5} \mathrm{Cu}_{2} \mathrm{Mg}_{8} \mathrm{Si}_{6}\right)$ 상, 바늘 형태의 $\beta-\mathrm{Fe}\left(\mathrm{Al}_{5} \mathrm{FeSi}\right)$ 상으로 구성되는 것을 확인할 수 있었다(그림 1(b)). 냉각 중 $\mathrm{Al}-\mathrm{Si}$ 공정 반응 후 에너지가 높은 공정상 계면에서 $\theta$ 상, $\beta-\mathrm{Fe}$ 상, $\mathrm{Q}$ 상이 정출된 것으로 추측된다. $\beta-\mathrm{Fe}$ 상은 잉고트 주조 중 함유된 미량의 $\mathrm{Fe}$ 에 의해 생성된 것으로, 높은 취성으로 인해 기계적 특성을 저하시킨다고 보고된다 [5].

용체화 열처리 조건을 선정하기 위하여 $\mathrm{DTA}$ 를 이용해 $\mathrm{Al}-5.2 \mathrm{Si}-3.4 \mathrm{Cu}-0.28 \mathrm{Mg}$ 합금의 승온 중 시차 열 분석을 실시 하였으며, 그 결과를 그림 2에 나타내었다. $480-620{ }^{\circ} \mathrm{C}$ 온도
Table 3. EDS results of phases in the alloy.

\begin{tabular}{ccccccc}
\hline \multicolumn{7}{c}{ Chemical composition (at\%) } \\
\hline Point & $\mathrm{Al}$ & $\mathrm{Si}$ & $\mathrm{Cu}$ & $\mathrm{Mg}$ & $\mathrm{Fe}$ & $\mathrm{O}$ \\
\hline 1 & 67.09 & 0.10 & 28.90 & 0.42 & 1.38 & 1.20 \\
\hline 2 & 17.98 & 34.18 & 9.54 & 37.02 & 0.71 & 0.56 \\
\hline 3 & 1.83 & 97.50 & 0.14 & 0.06 & 0.18 & 0.29 \\
\hline 4 & 65.56 & 17.83 & 1.18 & 1.36 & 15.07 & 1.00 \\
\hline
\end{tabular}

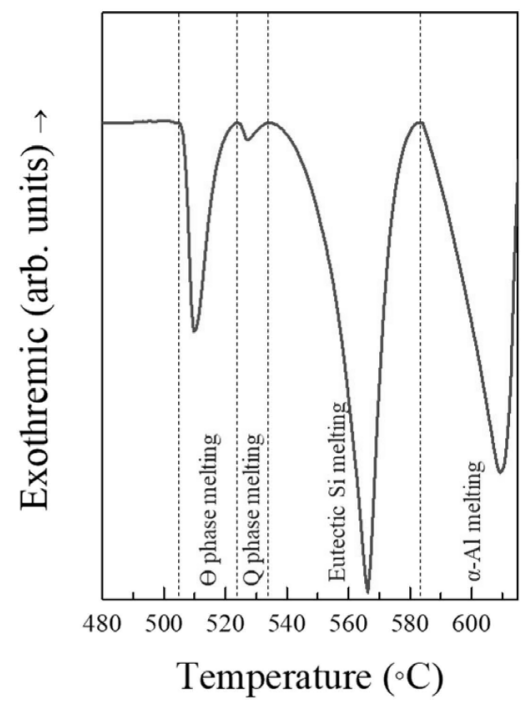

Fig. 2. DTA curve and its corresponding reactions of the alloy during heating.

범위 내에서 4 개의 흡열 반응이 존재하는 것을 확인할 수 있 다. 상온의 $\mathrm{Al}-\mathrm{Si}-\mathrm{Cu}-\mathrm{Mg}$ 합금에 존재하는 초정 $\mathrm{Al}$ 상, $\mathrm{Al}-\mathrm{Si}$ 공정상, $\theta$ 상, $\mathrm{Q}$ 상, $\beta-\mathrm{Fe}$ 상이 $504{ }^{\circ} \mathrm{C}$ 까지 존재한다. $504-524$ ${ }^{\circ} \mathrm{C}$ 및 $524-534{ }^{\circ} \mathrm{C}$ 구간에서는 각각 $\mathrm{Cu}$ 함유량이 높은 $\theta$ 상,
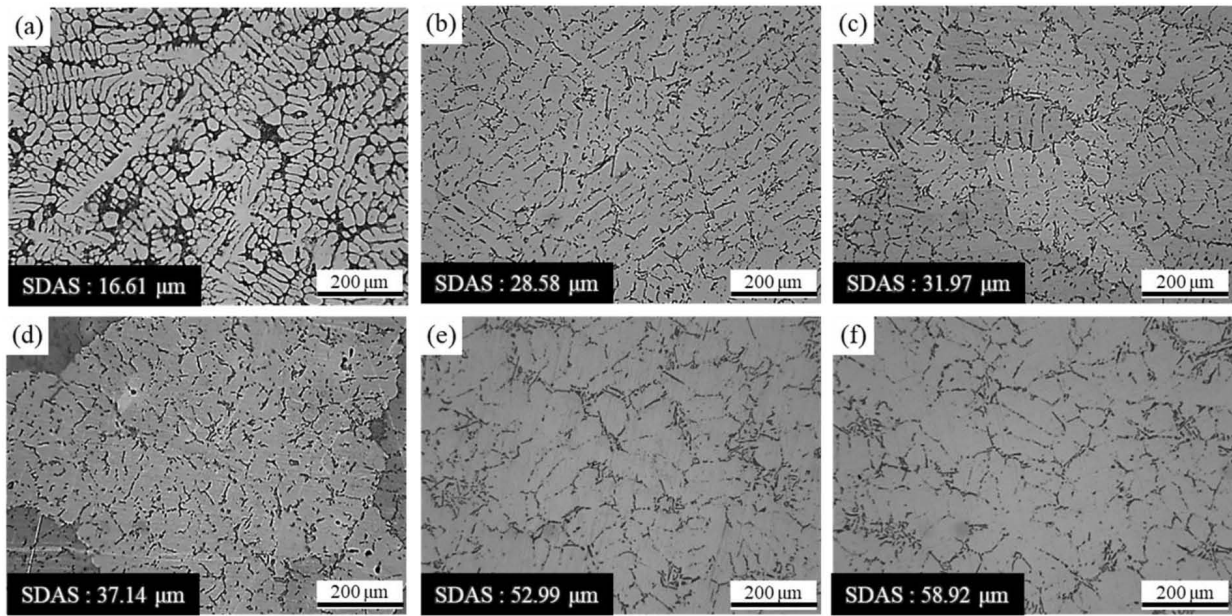

Fig. 3. Optical micrographs of the alloy (a) in as-cast, and solution-treated at $495{ }^{\circ} \mathrm{C}$ for (b) 5 , (c) 7 , (d) 9 , (e) 11 , and (f) 13 hours. 


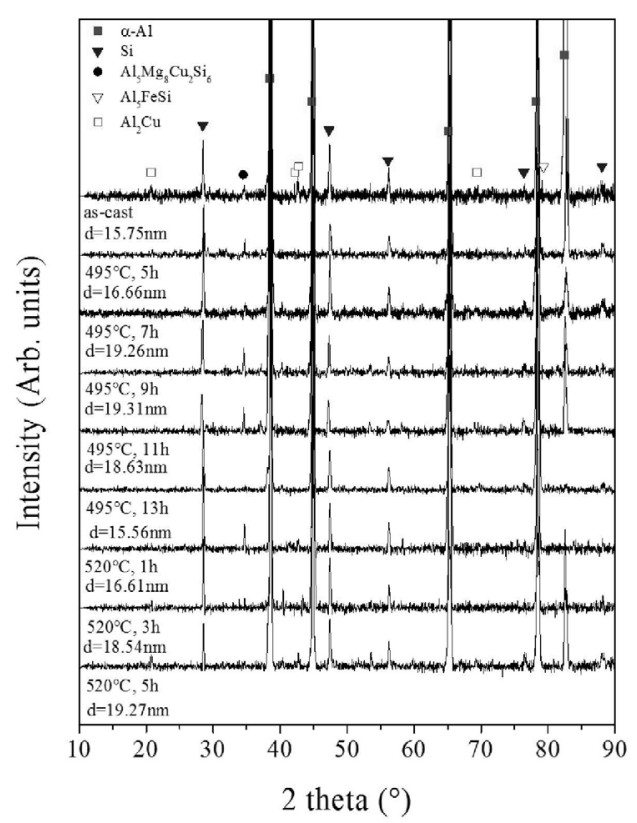

Fig. 4. X-ray diffraction patterns of the alloy before and after solution treatments. "d" denotes the interplanar spacing.

$\mathrm{Al}, \mathrm{Si}, \mathrm{Mg}, \mathrm{Cu}$ 로 구성된 Q상의 용융이 발생한다 [26,27]. $565-585{ }^{\circ} \mathrm{C}$ 범위는 $\mathrm{Al}-\mathrm{Si}$ 공정 반응 구간으로, 공정상의 용 융이 발생하여 $\mathrm{Al}-\mathrm{Si}$ 액상이 형성된다 [28]. $585{ }^{\circ} \mathrm{C}$ 는 초정 $\mathrm{Al}$ 상의 용융이 발생하는 온도로써 초정 $\mathrm{Al}$ 상 액상이 형성된다. 이러한 결과를 바탕으로 Al-5.2Si-3.4Cu-0.28 Mg 합금의 용 체화 열처리 온도를 선정하였다. 용체화 열처리는 시효 열처 리 시 미세하게 석출될 상들의 고용이 목적이기 때문에, $\theta$ 상 의 용융 온도 $\left(504{ }^{\circ} \mathrm{C}\right)$ 보다 낮은 $495{ }^{\circ} \mathrm{C}$ 를 열처리 온도로 선정
하였다. 또한 $\mathrm{Q}$ 상의 추가적인 고용을 위한 2 단 용체화 열처 리는 $\mathrm{Q}$ 상의 용융 온도 $\left(524{ }^{\circ} \mathrm{C}\right)$ 보다 낮은 $520{ }^{\circ} \mathrm{C}$ 에서 시도하 였다.

그림 3는 $\mathrm{Al}-5.2 \mathrm{Si}-3.4 \mathrm{Cu}-0.28 \mathrm{Mg}$ 합금의 $495{ }^{\circ} \mathrm{C}$ 용체화 열 처리 시간에 따른 미세조직 변화를 나타낸다. 용체화 열처리 시간이 증가함에 따라 2차 수지상 가지의 간격이 $16.6 \mu \mathrm{m}$ 에 서 $58.9 \mu \mathrm{m}$ 로 증가하고, 수지상정에서 등축정으로 변하는 것을 볼 수 있다. 이러한 현상은 $\mathrm{Si}, \mathrm{Cu}, \mathrm{Mg}$ 가 첨가된 $\mathrm{Al}$ 합금 의 용체화 열처리 거동에서 보고된 것과 유사하다.

그림 4는 $\mathrm{Al}-5.2 \mathrm{Si}-3.4 \mathrm{Cu}-0.28 \mathrm{Mg}$ 합금의 as-cast, $495{ }^{\circ} \mathrm{C}$ 용체화 열처리 시간, $520{ }^{\circ} \mathrm{C} 2$ 단 용체화 열처리 시간에 따른 $\mathrm{XRD}$ 결과를 나타낸다. $495{ }^{\circ} \mathrm{C}$ 에서 용체화 열처리가 실시됨 에 따라 $\theta$ 상이 고용되어 피크 강도가 감소하며, 9 시간까지 용 체화 처리한 $\alpha-\mathrm{Al}$ 의 면간거리(d, d-spacing)는 증가한다. 반면 에 $495{ }^{\circ} \mathrm{C}$ 에서 11 시간 이상 열처리한 합금에서 $\alpha-\mathrm{Al}$ 의 반치 전폭(full width of half maximum, FWHM)과 면간거리는 감 소하는데, Scherrer 방정식 [29]을 통해 결정 성장이 발생한 것을 확인할 수 있었다. 이는 결정립 성장이 관찰된 그림 3 의 결과와 일치한다. $520{ }^{\circ} \mathrm{C}$ 에서 2 단 용체화 열처리가 실시됨에 따라 $\mathrm{Q}$ 상의 피크 강도가 감소하며, $\mathrm{Al}$ 상의 면간거리는 증가 하는데 이를 통해 $\mathrm{Q}$ 상의 고용이 확인된다. $520{ }^{\circ} \mathrm{C}$ 에서 3 시간 이상 용체화 처리 시 $\mathrm{Q}$ 상이 대부분 고용되었을 것이라고 추 측된다.

그림 5는 $495{ }^{\circ} \mathrm{C}$ 에서 용체화 열처리된 $\mathrm{Al}-5.2 \mathrm{Si}-3.4 \mathrm{Cu}-$ $0.28 \mathrm{Mg}$ 합금의 $\mathrm{SEM}$ 으로 관찰한 미세조직 변화를 나타낸다. 열처리 시간의 증가에 따른 미세조직 변화 거동은 세 부분으
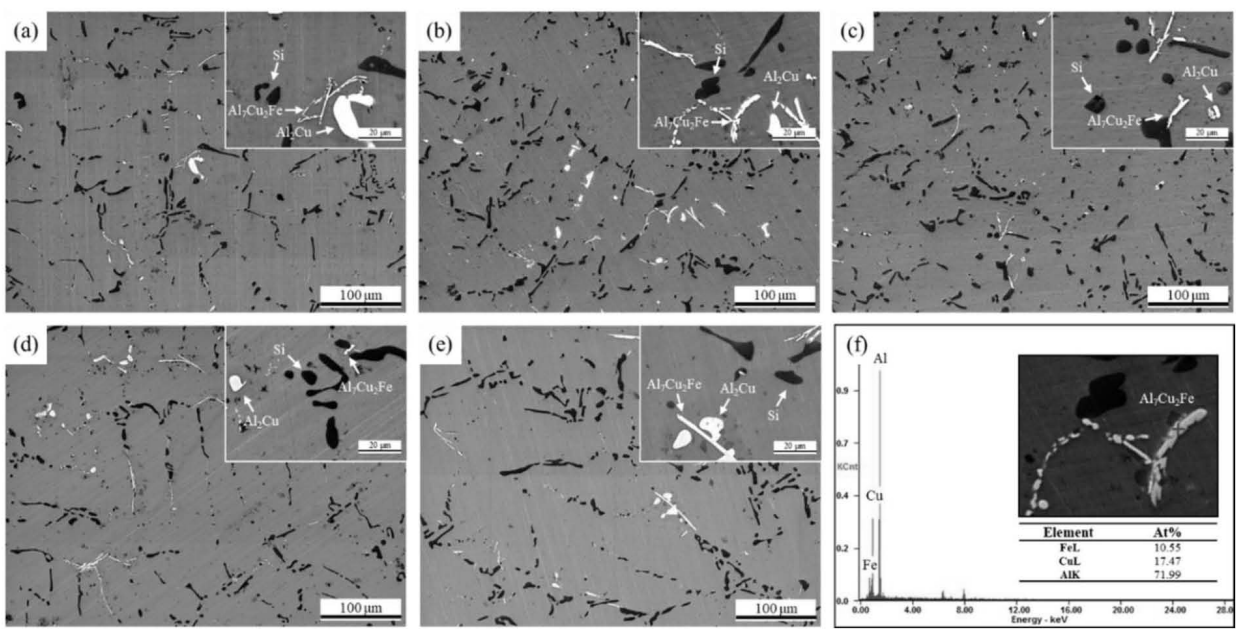

Fig. 5. SEM images of the solution-treated alloys held at $495{ }^{\circ} \mathrm{C}$ for (a) 5, (b) 7, (c) 9, (d) 11, and (e) 13 hours. (f) An EDS result of $\mathrm{Al}_{7} \mathrm{FeCu}_{2}$ phase. 

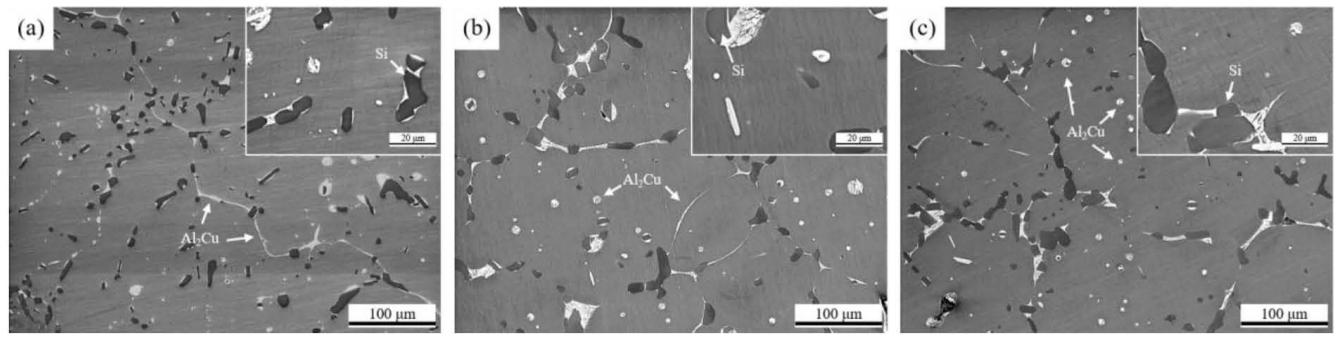

Fig. 6. SEM images of the alloys after 2-step solution treatments held at $520{ }^{\circ} \mathrm{C}$ for (a) 1 , (b) 3 , and (c) 5 hours.

로 설명할 수 있다. 첫 번째로 $\mathrm{Si}$ 공정상의 분해 및 구상화가 일어난다. 시간의 증가에 따라 확산 시간이 충분하게 확보되 면서 $\mathrm{Al}-\mathrm{Si}$ 계면을 통해 $\mathrm{Si}$ 원자가 상호 확산된 결과이다 [30]. 11 시간 이상에서는 $\mathrm{Si}$ 공정상의 조대화가 발생하는데, 이러 한 현상은 오스트발트 숙성(Ostwald ripening) 효과로 설명할 수 있다. 두 번째 미세조직 변화는 $\theta$ 상의 고용이다. 그림 1에 나타난 as-cast 미세조직에서 볼 수 있듯이, $\theta$ 상은 블록 형태 와 공정 형태로 존재한다. 용체화 열처리가 진행됨에 따라 as-cast에 나타난 공정 $\theta$ 상은 모두 용해되어 사라지지만, 블 록 형태의 $\theta$ 상은 13 시간 동안 완전히 용해되지 않고 구상화 되어 존재한다. 이는 공정상이 블록상에 비해 표면적이 커서 높은 에너지를 가지기 때문에, 공정상이 더 쉽게 용해된 것으 로 판단된다. 마지막 미세조직 변화는 $\beta-\mathrm{Fe}$ 상의 $\mathrm{Al}_{7} \mathrm{FeCu}_{2}$ 상 으로의 변태이다. 용체화 열처리 온도와 합금의 $\mathrm{Cu}, \mathrm{Mg}$ 함유 량에 따라 $\mathrm{Si}$ 공정상에 대한 $\beta-\mathrm{Fe}$ 와 $\mathrm{Al}_{7} \mathrm{FeCu}_{2}$ 상의 열적 안정 성이 달라진다고 알려져 있다 [31]. 본 합금은 $3.4 \mathrm{wt} \%$ 의 높 은 $\mathrm{Cu}$ 를 함유하기 때문에, 고용된 $\theta$ 상에 의해 고용체 내에 존 재하는 충분한 $\mathrm{Cu}$ 원자가 열처리 중 $\beta-\mathrm{Fe}$ 상로 확산하여, $\beta$ $-\mathrm{Fe}$ 상이 $\mathrm{Al}_{7} \mathrm{FeCu}_{2}$ 상으로 변태하면서 $\mathrm{Si}$ 공정상과 평형을 이 루는 것으로 사료된다. 용체화 열처리 중 $\beta-\mathrm{Fe}$ 와 $\mathrm{Al}_{7} \mathrm{FeCu}_{2}$ 상 의 중간상으로 예상되는 $\mathrm{AlSiFeCu}$ 상이 나타난다고 보고되 었지만 [15], 본 연구에서는 긴 열처리 시간으로 인한 충분한 확산으로 인해 존재하지 않는 것으로 판단된다. XRD 결과에 서 나타나지 않은 $\theta$ 상이 SEM 미세조직에 나타난 이유는 기 지 내 낮은 블록 형태의 $\theta$ 상 분율로 인한 것으로 추측된다.

$495{ }^{\circ} \mathrm{C}$ 에서 용체화 열처리 후 잔류하는 $\mathrm{Q}$ 상을 추가로 고 용시켜 과포화 고용체를 형성하기 위해, $520{ }^{\circ} \mathrm{C}$ 로 승온시켜 $1-5$ 시간동안 2 단 열처리를 실시하였고, 그 시편의 미세조 직 사진은 그림 6 에 나타내었다. $520{ }^{\circ} \mathrm{C}$ 에서 열처리한 모든 시편에서 $\mathrm{Q}$ 상은 완전히 고용되어 사라졌으나, $\mathrm{Si}$ 공정상의 조대화가 발생하였다. 주목할만한 결과는 $495{ }^{\circ} \mathrm{C}$ 에서 고용 되지 못하고 잔류하던 블록 형태의 $\theta$ 상이 용융된 흔적들이

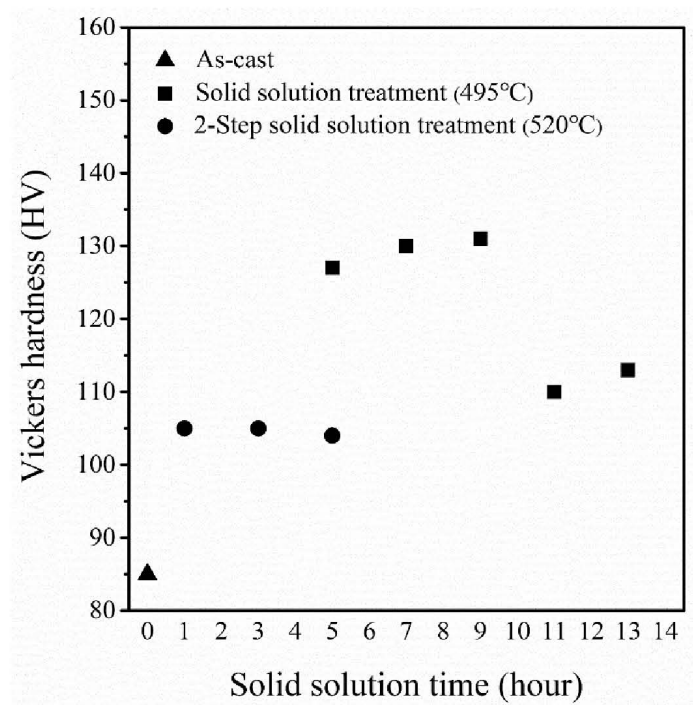

Fig. 7. Vickers hardnesses of the as-cast, 1-step, and 2-step solution-treated alloys.

다. 1 시간에서는 주로 에너지가 높은 입계에서 우선적으로 용융되고, 시간이 증가할수록 입계 뿐만 아니라 입내에서 액 적(droplet)을 형성하며 용융된 것으로 판단된다. 열처리 온 도가 증가함에도 불구하고 침상의 $\mathrm{Al}_{7} \mathrm{FeCu}_{2}$ 은 조대화되거나 고용되지 않는 것으로 보아, 높은 열적 안정성을 가지는 것으 로 사료된다.

최적의 용체화 열처리 공정의 선정을 위해 고용체의 경도 를 측정하였고, 그 결과를 그림 7에 나타내었다. $495{ }^{\circ} \mathrm{C}$ 에서 용체화 열처리를 진행함에 따라 9 시간까지 경도가 증가하였 으나, 11 시간 이후부터 급격히 감소하였다. 이러한 경도의 변 화는 그림 2에 나타난 2차수지간격(secondary dendrite and spacing, SDAS)와 그림 5 에 나타난 $\mathrm{Si}$ 공정상과 $\theta$ 상의 거동 을 통해 설명할 수 있다. 9 시간까지는 열처리 시간의 증가에 따른 결정립 조대화에 의한 연화 효과보다, $\mathrm{Si}$ 공정상의 분해 및 구상화에 의한 Orowan 강화 효과와 $\theta$ 상의 용해에 의한 고 용 강화 효과가 더 크기 때문에 경도가 증가하는 것으로 사료 

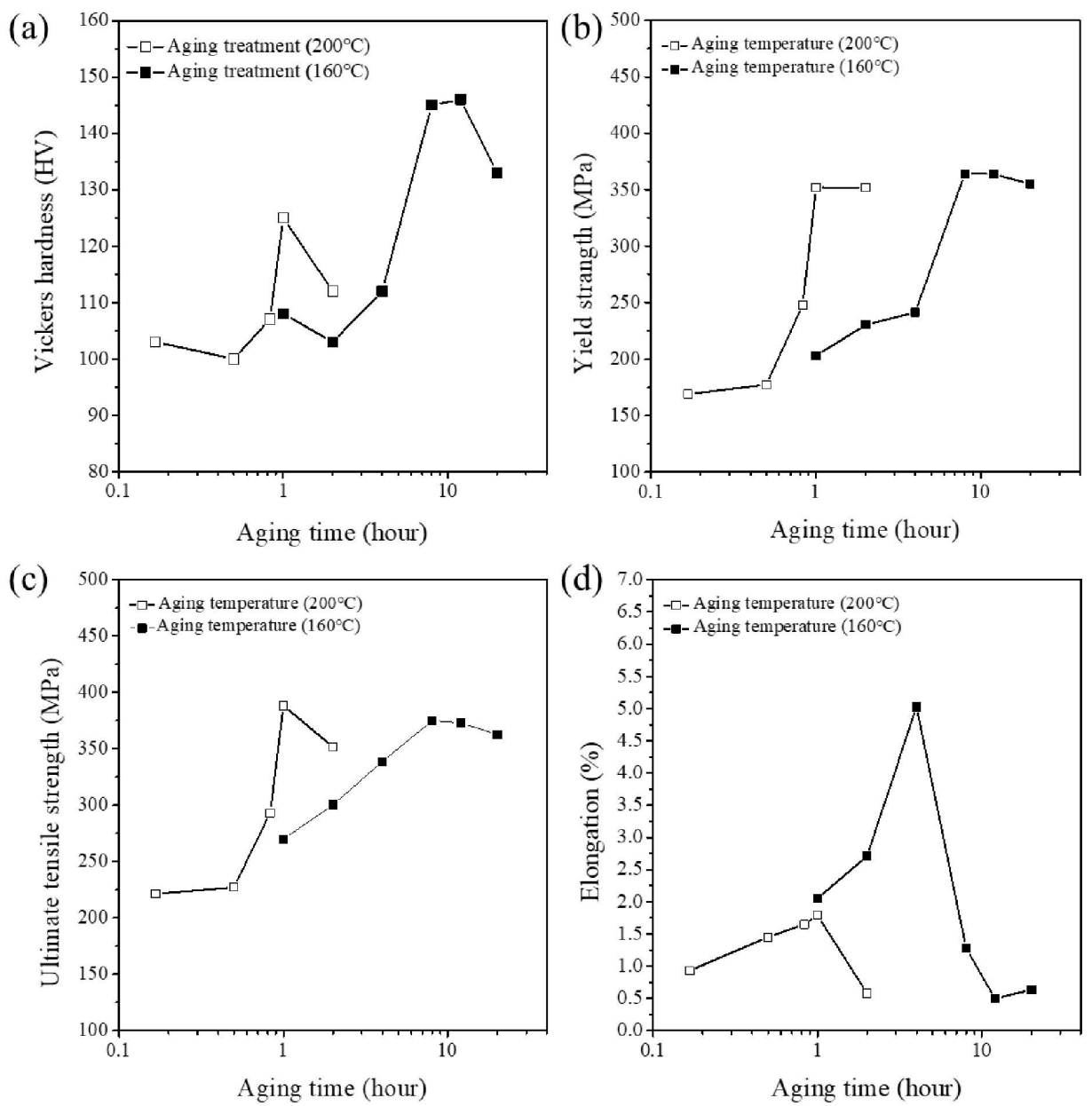

Fig. 8. Mechanical properties of the artificial aged $\mathrm{Al}-5.2 \mathrm{Si}-3.4 \mathrm{Cu}-0.28 \mathrm{Mg}$ alloy at 160 and $200{ }^{\circ} \mathrm{C}$ for various holding times: (a) hardness, (b) yield strength, (c) ultimate tensile strength, and (d) elongation.

된다. Orowan 강화 효과는 경한 상들이 균일하게 분산되어 각 상들 간의 거리가 짧을수록 크게 나타난다. 하지만 11시간 이후에는 블록 형태의 $\theta$ 상의 느린 고용 속도와 결정립 및 $\mathrm{Si}$ 공정상의 조대화로 인해 급격한 경도 감소가 발생하는 것으 로 판단된다. $520{ }^{\circ} \mathrm{C}$ 에서 2 단 용체화 열처리한 시편의 경우, $495{ }^{\circ} \mathrm{C}$ 에서 1 단 열처리한 시편보다 낮은 경도값을 나타내었 다. 이 현상은 그림 6에서 나타난 두 가지 조직 변화로 설명할 수 있다. 첫 번째는 결정립, $\mathrm{Si}$ 공정상의 조대화로, 결정립과 $\mathrm{Si}$ 공정상이 조대해지면 Orowan 및 Hall-Petch 강화 기구에 의한 전위 이동 방해 효과가 감소한다. 두 번째는 잔류 $\theta$ 상의 입계 및 입내에서의 용융 현상으로, 용융 부위에 국부적인 기 공을 형성시킨다 $[19,20]$. 이러한 원인들로 인해 2단 용체화 열처리를 시행하면 경도가 감소된 것으로 사료된다. 열처리 시간이 증가함에 따라 나타나는 미세한 경도 감소는 입내에 서 추가적인 $\theta$ 상의 용융이 발생하여 입계, 입내 모두 기공이
형성되기 때문이다.

$\mathrm{Si}, \mathrm{Cu}, \mathrm{Mg}$ 를 첨가 원소로 함유하는 $\mathrm{Al}$ 합금의 용체화 공 정은 주 고용상인 $\theta$ 상을 최대한 용해시키고, 결정립 성장과 제 2상들의 용융을 억제할 수 있는 온도와 시간에서 실시되 어야 한다. 따라서 앞서 언급한 결과들을 토대로, 용체화 열 처리 조건을 $495{ }^{\circ} \mathrm{C}, 9$ 시간으로 선정하였다.

앞서 언급한 바와 같이 $\mathrm{Al}-\mathrm{Si}-\mathrm{Cu}-\mathrm{Mg}$ 계 합금은 $150-240{ }^{\circ} \mathrm{C}$ 에서 시효 열처리를 실시하는데, $170{ }^{\circ} \mathrm{C}$ 이하에서 열처리를 실시하면 최대 경화에 도달하기 위한 시간은 증가하지만 높은 강도 및 경도가 얻어진다고 보고된다. 반면, $200{ }^{\circ} \mathrm{C}$ 이상에서 는 상대적으로 짧은 시간에서 최대 경화에 도달하지만, 170 ${ }^{\circ} \mathrm{C}$ 이하에 비해 최대 강도 및 경도가 낮다 $[12,15]$. 하지만 짧은 열처리 시간은 제조 공정의 경제성과 직결되기 때문에, 기계 적 강도의 감소가 크지 않다면 공정에서 고려할 수 있는 선택 지가 될 수 있다. 따라서 본 연구에서는 $495{ }^{\circ} \mathrm{C}$ 에서 9 시간 동안 
용체화 열처리 후, 시효 열처리에 따른 기계적 특성 변화를 관 찰하기 위해 $160,200{ }^{\circ} \mathrm{C}$ 에서 시효를 실시하였다.

$495{ }^{\circ} \mathrm{C}$ 에서 9 시간 동안 용체화 열처리 후, 시효 열처리에 따른 기계적 특성 변화를 관찰하기 위해 $160,200{ }^{\circ} \mathrm{C}$ 에서 시 효를 실시하였다. 열처리된 시편들의 시효 열처리 시간에 따 른 경도, 항복강도, 인장강도 및 연신율 시험 결과를 그림 8에 나타내었다. 경도와 항복강도, 인장강도는 각 시효 열처리 온 도에서 시간에 따라 같은 변화 양상을 나타냈다. $160{ }^{\circ} \mathrm{C}$ 에서 연신율은 경도, 강도와 반비례하는 반면, $200{ }^{\circ} \mathrm{C}$ 열처리는 경 도, 강도가 증가함에 따라 연신율도 증가하였다. $200{ }^{\circ} \mathrm{C}$ 에서 는 짧은 시간 동안 시효 처리로 높은 강도를 얻을 수 있었으 나, 낮은 연신율을 나타냈다. 최대 경도 및 강도는 $160{ }^{\circ} \mathrm{C} / 12$ 시간 조건에서 얻을 수 있었고, $160{ }^{\circ} \mathrm{C} / 4$ 시간 조건에서 가장 높은 연신율을 얻을 수 있었다. $160{ }^{\circ} \mathrm{C}$ 에서 12 시간 이후, 200 ${ }^{\circ} \mathrm{C}$ 에서 1 시간 이후의 경도 감소는 $\theta^{\prime \prime}$ 상 또는 $\theta^{\prime}$ 상의 부정합 $\theta$ 상으로의 변태와 $\theta$ 상의 조대화로 인한 과시효 현상에 기인한 것이다 [6]. 적절한 강도와 연신율을 얻기 위한 시효 열처리 조건은 $160{ }^{\circ} \mathrm{C} / 4$ 시간인 것으로 확인되었다.

본 연구의 $\mathrm{Al}-5.2 \mathrm{Si}-3.4 \mathrm{Cu}-0.28 \mathrm{Mg}$ 합금은 기존에 보고된 $\mathrm{Al}-\mathrm{Si}-\mathrm{Cu}-\mathrm{Mg}$ 계 합금보다 $\mathrm{Si}$ 첨가량을 낮추고, 중간 정도의 $\mathrm{Cu}+\mathrm{Mg}$ 첨가량 및 $\mathrm{Cu} / \mathrm{Mg}$ 비의 조성으로 $400 \mathrm{MPa}$ 수준의 강 도 또는 $5 \%$ 이상의 연신율을 나타내는 열처리 조건을 도출 하였다. Al-Si-Cu-Mg계 합금의 파괴의 기점은 조대한 공정 $\mathrm{Si}$ 입자 또는 $\mathrm{Fe}$ 를 함유하는 취성의 화합물에서 주로 일어난 다고 보고된다 [32]. 본 합금에서 $\mathrm{Si}$ 첨가량의 감소는 $\mathrm{Si}$ 공정 상의 분율을 저하시켜 강도를 감소시키지만, 이에 따른 파괴 의 기점이 감소되어 상대적인 연성의 증가가 발생한 것으로 사료된다. 그리고 연성의 증가는 $495{ }^{\circ} \mathrm{C} / 9$ 시간 용체화 열처 리를 통해 얻은 미세하게 분포된 $\mathrm{Si}$ 공정상 또한 전위의 이동 을 방해하기 때문이다. $\mathrm{Si}$ 첨가량 감소에 의한 강도 감소분은 중간 정도의 $\mathrm{Cu}+\mathrm{Mg}$ 첨가량 및 $\mathrm{Cu} / \mathrm{Mg}$ 비로 조대한 $\beta$ 상의 생성을 억제하고 $\theta$ 상을 생성시켜, 열처리 후 $\theta^{\prime \prime}$ 또는 $\theta^{\prime}$ 상의 미세한 석출을 통해 보상된 것으로 생각된다. 또한 연신율을 저하시킨다고 보고된 취성의 $\beta-\mathrm{Fe}$ 를 $\mathrm{Al}_{7} \mathrm{FeCu}_{2}$ 로 치환하여 연성을 확보한 것으로 판단된다 $[6,15,31]$.

\section{4. 결 론}

본 연구에서는 $\mathrm{Al}-5.2 \mathrm{Si}-3.4 \mathrm{Cu}-0.28 \mathrm{Mg}$ 합금의 미세조직 및 기계적 특성에 미치는 용체화 및 시효 열처리 효과에 대해 서 고찰한 결과 다음과 같은 결론을 도출하였다.
1. As-cast 상태의 Al-5.2Si-3.4Cu-0.28Mg 합금의 미세조 직은 $\alpha-\mathrm{Al}, \mathrm{Si}$ 공정상, $\theta$ 상, $\mathrm{Q}$ 상, $\beta-\mathrm{Fe}$ 상으로 구성됨을 확인하였다.

2. 여러 온도 $\left(495,520{ }^{\circ} \mathrm{C}\right)$ 에서 용체화 열처리한 결과, $495{ }^{\circ} \mathrm{C} / 9$ 시간 조건에서 가장 높은 경도를 얻을 수 있었 다. $520{ }^{\circ} \mathrm{C}$ 2단 용체화 열처리는 $\mathrm{Q}$ 상의 고용을 도모할 수 있었지만, 잔류 $\theta$ 상의 용융으로 인해 경도가 감소하 였다.

3. $160,200{ }^{\circ} \mathrm{C}$ 에서 시효 처리한 결과, $160{ }^{\circ} \mathrm{C} / 12$ 시간 시효 에서 가장 높은 경도 및 강도를 얻을 수 있었고, $160{ }^{\circ} \mathrm{C}$ $/ 4$ 시간 시효에서 $5 \%$ 이상의 연신율을 나타냈다. 연성 의 증가는 미세하게 분포된 $\mathrm{Si}$ 공정상, $\beta$ 상의 생성 억 제, $\beta$ - $\mathrm{Fe}$ 의 $\mathrm{Al}_{7} \mathrm{FeCu}_{2}$ 로의 치환으로 설명된다. $200{ }^{\circ} \mathrm{C}$ 에 서는 짧은 시간 동안 시효 처리로 높은 강도를 얻을 수 있었으나, 낮은 연신율을 나타냈다.

4. $495{ }^{\circ} \mathrm{C} / 9$ 시간 용체화 열처리 후 $160{ }^{\circ} \mathrm{C} / 4$ 시간 시효 열 처리가 적절한 강도 및 연신율을 얻기 위한 최적 조건 으로 판단된다.

\section{감사의 글}

이 논문은 2017년도 정부(교육부)의 재원으로 한국연구재 단의 지원을 받아 수행된 기초연구사업임(No. NRF-2016R1 D1A3B03933650).

\section{REFERENCES}

1. M. Javidani and D. Larouche, Int. Mater. Rev. 59, 132 (2014).

2. H. Zandbergen, S. Andersen, and J. Jansen, Science 277, 1221 (1997).

3. C. Caceres, C. Davidson, J. Griffiths, and Q. Wang, Metall. Mater. Trans. A 30, 2611 (1999).

4. M. Yildırım and D. Özyürek, Mater. Design 51, 767 (2013).

5. Z. Ma, A. Samuel, F. Samuel, H. Doty, and S. Valtierra, Mater. Sci. Eng. A 490, 36 (2008).

6. E. Sjölander and S. Seifeddine, J. Mater. Process. Tech. 210, 1249 (2010).

7. F. Paray, B. Kulunk, and J. Gruzleski, Int. J. Cast Metal. Res. 13, 147 (2000).

8. S. Zor, M. Zeren, H. Ozkazanc, and E. Karakulak, Anti-Corros. Method. M. 57, 185 (2010).

9. F. Grosselle, G. Timelli, and F. Bonollo, Mater. Sci. Eng. A 527, 3536 (2010).

10. B.-R. Jin and C.-Y. Jeong, Korean J. Met. Mater. 54, 626 
(2016).

11. C. Caceres, I. L. Svensson, and J. Taylor, Int. J. Cast Metal. Res. 15, 531 (2003).

12. E. Sjölander and S. Seifeddine, Mater. Sci. Eng. A 528, 7402 (2011).

13. Y. Zheng, W. Xiao, S. Ge, W. Zhao, S. Hanada, and C. Ma, J. Alloy. Compd. 649, 291 (2015).

14. F. Tavitas-Medrano, A. M. Mohamed, J. Gruzleski, F. Samuel, and H. Doty, J. Mater. Sci. 45, 641 (2010).

15. E. Cerri, E. Evangelista, S. Spigarelli, P. Cavaliere, and F. DeRiccardis, Mater. Sci. Eng. A 284, 254 (2000).

16. F. Tavitas-Medrano, J. Gruzleski, F. Samuel, S. Valtierra, and H. Doty, Mater. Sci. Eng. A 480, 356 (2008).

17. Y. J. Li, S. Brusethaug, and A. Olsen, Scripta Mater. 54, 99 (2006).

18. G. Wang, Q. Sun, L. Feng, L. Hui, and C. Jing, Mater. Design 28, 1001 (2007).

19. P. Ouellet and F. H. Samuel, J. Mater. Sci. 34, 4671 (1999).

20. F. H. Samuel, J. Mater. Sci. 33, 2283 (1998).

21. J. H. Sokolowski, X. C. Sun, G. Byczynski, D. O. Northwood, D. E. Penrod, R. Thomas, and A. Esseltine, J. Mater. Process. Technol. 53, 385 (1995).

22. A. Mohamed and F. Samuel, Mat. Sci. Eng. A 577, 64
(2013)

23. A. Farkoosh, X. G. Chen, and M. Pekguleryuz, Mater. Sci. Eng. A 627, 127 (2015).

24. D. A. Lados, D. Apelian, and L. Wang, Metall. Mater. Trans. B 42, 171 (2011).

25. R. Li, AFS Trans. 104, 777 (1996).

26. J. Zhao and S. Wu, Trans. Nonferrous Met. Soc. China 20, s754 (2010).

27. P. Kapranos, D. H. Kirkwood, H. V. Atkinson, J. T. Rheinlander, J. J. Bentzen, P. T. Toft, C. P. Debel, G. Laslaz, L. Maenner, S. Blais, J. M. Rodriguez-Ibabe, L. Lasa, P. Giordano, G. Chiarmetta, and A. Giese, J. Mater. Process. Tech. 135, 271 (2003).

28. K. M. Sree Manu, K. Sreeraj, T. P. D. Rajan, R. M. Shereema, B. C. Pai, and B. Arun, Mater. Design 88, 294 (2015).

29. P. Scherrer, Göttinger Nachrichten Math. Phys. 2, 98 (1918).

30. E. Ogris, A. Wahlen, H. Lüchinger, and P. J. Uggowitzer, J. Light Met. 2, 263 (2002).

31. A. Lise Dons, J. Light Met. 1, 133 (2001).

32. A. M. Samuel and F. H. Samuel, Metall. Mater. Trans. A 26, 2359 (1995). 